Simona Ghita*, Emilia Titan**

\title{
Analysis of Products Demand on E.U. Markets Based on Commerce Activity of Large Stores
}

\section{Summary}

Retail in large store-chains extended in well-developed countries. 465 millions inhabitants express their supply on their markets; between 2000 and 2005 sales values were increasing; the increase-sources were the promotional prices, as well as the European buyers' availability to respond to the supply's diversity. After the political events that happened after 1989, in Romania appeared large hypermarket-chains and supermarket-chains, most of them being transnational companies that developed their own business in our country. Due to these commercial-units, the retail-value in Romania grew in a spectacular way, with more than 85\% during 2000-2005 period, although from the retail-value per inhabitant point of view, we are far behind other European countries' level. The number of retail-commercial units, as well as the sales-purchasing value in these units characterizes the commercial sector situation in a country. For a comparative analysis at territorial level, for different European Union's countries, we will realize a multicriterial hierarchy, based on the two statistical indicators previously mentioned, and on other two general macroeconomic indicators: Gross Domestic Product (GDP) per inhabitant and unemployment-rate.

The main European Union's countries hierarchy based on the four criteria was realized by two statistical methods: the ranks' method and the relative-distance method from the maximum performance unit.

* Ph.D., Academy of Economic Studies, Bucharest, Romania.

** Ph.D., Academy of Economic Studies, Bucharest, Romania. 


\section{Introduction}

In the last decades, the supermarkets' and hypermarkets' commercial activity boomed in a spectacular way: in all the twenty analyzed countries the retail-value was, in 2005 , of 2100000 millions euros and it was still increasing after 2000 year, due to the promotional prices and the diversified supply (Hamson, 2006; Gauthier, 2004; Euromonitor, 2006).

Retail in large store-chains extended in well-developed countries. 465 millions inhabitants express their supply on their markets; sales values evolution was an increasing one, between 2000 and 2005 year; the increase-sources were the promotional prices, as well as the European buyers' availability to respond to the supply's diversity.

Statistical methods applied in spatial data analysis were largely studied by Kangas, Leskinen and Kangas (2007), Leskinen and Kangas (2005), Rondinelli (1996), BanaiKashani (1989).

For a comparative analysis at territorial level, for different European Union's countries, we realized a multicriterial hierarchy, based on the two statistical indicators previously mentioned, and on other two general macroeconomic indicators: Gross Domestic Product (GDP) per inhabitant and unemployment-rate.

The main European Union's countries hierarchy based on the four criteria was realized by two statistical methods: the ranks' method and the relative-distance method from the maximum performance unit.

In the period before the European Integration, the Romanian retail commerce experienced an unknown development, a natural one, if we take into consideration the evolution rhythm of the economical and social systems in European countries, as well as in the entire world. In Romania appeared large hypermarket-chains and supermarket-chains, most of them being transnational companies that developed their own business in our country. Due to these commercial-units, the retail-value in Romania grew in a spectacular way, with more than 85\% during 2000-2005 period, although from the retail-value per inhabitant point of view, we are far behind other European countries' level (graphic no. 1).

Graphic no. 1. The sales - purchasing evolution in retail commercial stores, in some European countries, in 2000-2005

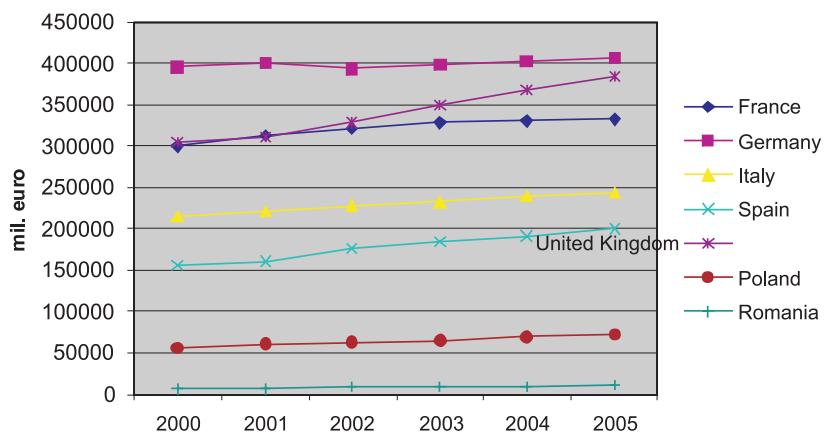

Source: National statistics, Eurostat, Euromonitor 2006. 
Graphic no. 2. The retail commercial units' evolution in some European countries, during 2000-2005

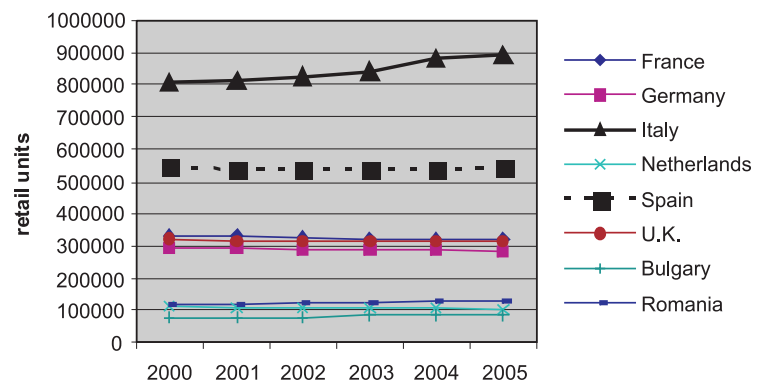

Source: National statistics, Eurostat, Euromonitor 2006, commercial press.

The number of retail-commercial stores had a similar evolution in the main European countries. The top-countries were France, Germany, Great Britain, Italy, while the recent joined European Union countries were situated at the opposite pole. (Graphic no. 2)

The number of retail-commercial units, as well as the sales-purchasing value in these units characterizes the commercial sector situation in a country. For a comparative analysis at territorial level, for different European Union's countries, we will realize a multicriterial hierarchy, based on the two statistical indicators previously mentioned, and on other two general macroeconomic indicators: Gross Domestic Product (GDP) per inhabitant (2004) and unemployment-rate (2004).

The main European Union's countries hierarchy based on the four criteria was realized by two statistical methods: the ranks' method and the relative-distance method from the maximum performance unit.

\section{Ranks' method}

There have been attributed order-numbers (ranks) to the territorial units (countries), related to the each statistical indicators' value that was considered as a hierarchy criteria: the best performance unit - gets the first rank, the following unit - gets the second rank, and so on, until the last unit, with the worst performance - that gets the „n” rank. The sum of the ranks represents a score. The territorial unit with the minimum score is the one with the best performance, considering the 4 criteria (it has the final rank 1). As the score grows, so does the final range, until the ,, " rank - assigned to the maximum score unit.

The results of the Ranks' method are: the best situated countries (according to the four criteria) are: Great Britain, followed by the Netherlands and Italy. On the following places ranked France and Germany. To the opposite places are situated the most disadvantaged countries (referring to the four criteria). They are the same countries that joined most recently the European Union: Slovakia, Bulgaria and Romania.

The ranks' method can be easily and quickly applied, but it has a disadvantage: it double-equalizes the differences between the territorial units, and replaces them with an arithmetic progression with ratio 1 . So, a great amount of information is practically lost. 
Table 1. The hierarchy-criteria for European countries in 2004

\begin{tabular}{|c|c|c|c|c|}
\hline Country & $\begin{array}{l}\text { Sales-purchasing value in } \\
\text { retail units (mill. Euros) }\end{array}$ & $\begin{array}{l}\text { Commercial retail } \\
\text { units (number) }\end{array}$ & $\begin{array}{l}\text { Unemployment } \\
\text { rate (\%) }\end{array}$ & $\begin{array}{l}\text { GDP/pers. } \\
\text { (Euros/pers.) }\end{array}$ \\
\hline Austria & 42893,1 & 53941 & 4,9 & 28.800 \\
\hline Belgium & 58691,05 & 88610 & 8,2 & 27.800 \\
\hline Denmark & 29406,95 & 24374 & 5,6 & 36.500 \\
\hline Finland & 30 207,36 & 25087 & 8,8 & 29.100 \\
\hline France & 331238,5 & 323408 & 9,9 & 26.600 \\
\hline Germany & 402399,9 & 285705 & 11,0 & 26.800 \\
\hline Greece & 36178,89 & 149496 & 8,9 & 15.200 \\
\hline Ireland & 33103,17 & 29401 & 4,5 & 36.400 \\
\hline Italy & 238423,1 & 883431 & 8,7 & 23.900 \\
\hline Netherlands & 89142,28 & 105339 & 4,3 & 30.100 \\
\hline Portugal & 26476,83 & 52524 & 6,3 & 13.600 \\
\hline Spain & 191908,2 & 537440 & 11,0 & 19.700 \\
\hline Sweden & 44877,45 & 48835 & 5,5 & 31.400 \\
\hline Great Britain & 368266,2 & 317861 & 4,6 & 29.000 \\
\hline Czeck Rep. & 23055,59 & 89629 & 8,3 & 8.500 \\
\hline Hungary & 19094,23 & 149386 & 6,1 & 8.100 \\
\hline Poland & 69303,33 & 323641 & 19,0 & 5.300 \\
\hline Slovakia & 6939,36 & 43186 & 18,1 & 6.300 \\
\hline Bulgaria & 5704,41 & 82429 & 12,0 & 2.500 \\
\hline Romania & 9308,97 & 127649 & 8,0 & 2.806 \\
\hline
\end{tabular}

Table 2. Ranks' method application results for countries hierarchy

\begin{tabular}{|c|c|c|c|c|c|c|}
\hline \multirow[b]{2}{*}{ Country } & \multicolumn{4}{|c|}{ Ranks for: } & \multirow[b]{2}{*}{ Score } & \multirow[b]{2}{*}{ Final Rank } \\
\hline & $\begin{array}{l}\text { Sales-purchasing } \\
\text { value in retail units }\end{array}$ & $\begin{array}{l}\text { Commercial } \\
\text { retail units }\end{array}$ & $\begin{array}{l}\text { Unemployment } \\
\text { rate }\end{array}$ & GDP/pers & & \\
\hline Austria & 10 & 14 & 4,0 & 7 & 35,0 & 8,0 \\
\hline Belgium & 8 & 12 & 10,0 & 8 & 38,0 & 10,0 \\
\hline Denmark & 14 & 20 & 6,0 & 1 & 41,0 & 11,0 \\
\hline Finland & 13 & 19 & 13,0 & 5 & 50,0 & 15,0 \\
\hline France & 3 & 4 & 15,0 & 10 & 32,0 & 4,0 \\
\hline Germany & 1 & 6 & 16,5 & 9 & 32,5 & 5,0 \\
\hline Greece & 11 & 7 & 14,0 & 13 & 45,0 & 12,0 \\
\hline Ireland & 12 & 18 & 2,0 & 2 & 34,0 & 7,0 \\
\hline Italy & 4 & 1 & 12,0 & 11 & 28,0 & 3,0 \\
\hline Netherlands & 6 & 10 & 1,0 & 4 & 21,0 & 2,0 \\
\hline Portugal & 15 & 15 & 8,0 & 14 & 52,0 & 16,0 \\
\hline Spain & 5 & 2 & 16,5 & 12 & 35,5 & 9,0 \\
\hline
\end{tabular}




\begin{tabular}{|l|c|c|c|c|c|c|}
\hline \multirow{2}{*}{ Country } & \multicolumn{4}{|c|}{ Ranks for: } & \multirow{2}{*}{ Score } & \multirow{2}{*}{ Final Rank } \\
\cline { 2 - 5 } & $\begin{array}{c}\text { Sales-purchasing } \\
\text { value in retail units }\end{array}$ & $\begin{array}{c}\text { Commercial } \\
\text { retail units }\end{array}$ & $\begin{array}{c}\text { Unemployment } \\
\text { rate }\end{array}$ & GDP/pers & & \\
\hline Sweden & 9 & 16 & 5,0 & 3 & 33,0 & 6,0 \\
\hline Great Britain & 2 & 5 & 3,0 & 6 & 16,0 & 1,0 \\
\hline Czech Rep. & 16 & 11 & 11,0 & 15 & 53,0 & 17,0 \\
\hline Hungary & 17 & 8 & 7,0 & 16 & 48,0 & 13,5 \\
\hline Poland & 7 & 3 & 20,0 & 18 & 48,0 & 13,5 \\
\hline Slovakia & 19 & 17 & 19,0 & 17 & 72,0 & 20,0 \\
\hline Bulgaria & 20 & 13 & 18,0 & 20 & 71,0 & 19,0 \\
\hline Romania & 18 & 9 & 9,0 & 19 & 55,0 & 18,0 \\
\hline
\end{tabular}

\section{The relative distance from the maximum performance method}

The relative distance from the maximum performance method removes some of the ranks' method disadvantages, obtaining a clearer hierarchy of the territorial units. For each hierarchy criteria, we compute the relative distance of every territorial unit from the maximum level one. The distance is expressed by coordination-indicators whose values are less than 1 . We then compute the geometric average of the coordination indicators, expressing the average distance at which a certain territorial-unit is situated, from a hypothetical one. The hypothetical unit is the one that obtains the maximum performance for all the criteria in the same time.

Table 3. The results of the relative distance' method application

\begin{tabular}{|c|c|c|c|c|c|c|c|}
\hline \multirow[b]{2}{*}{ Country } & \multicolumn{4}{|c|}{ Relative distances for: } & \multirow[b]{2}{*}{$\begin{array}{l}\text { Average } \\
\text { distance }\end{array}$} & \multirow[b]{2}{*}{$\begin{array}{l}\text { Final } \\
\text { rank }\end{array}$} & \multirow{2}{*}{$\begin{array}{c}\text { Position } \\
\text { to the } \\
\text { maximum } \\
\text { performance } \\
\text { unit (\%) }\end{array}$} \\
\hline & $\begin{array}{c}\text { Sales- } \\
\text { purchasing } \\
\text { value in retail } \\
\text { units }\end{array}$ & $\begin{array}{l}\text { Commercial } \\
\text { retail units }\end{array}$ & $\begin{array}{l}\text { Unemploy } \\
\text { ment rate }\end{array}$ & GDP/pers & & & \\
\hline Austria & 0,106 & 0,061 & 0,877 & 0,789 & 0,259 & 8 & 36,84 \\
\hline Belgium & 0,146 & 0,100 & 0,524 & 0,762 & 0,276 & 7 & 39,26 \\
\hline Denmark & 0,073 & 0,027 & 0,768 & 1,000 & 0,197 & 13 & 28,02 \\
\hline Finland & 0,075 & 0,028 & 0,489 & 0,797 & 0,169 & 16 & 24,04 \\
\hline France & 0,823 & 0,366 & 0,434 & 0,729 & 0,555 & 3 & 78,95 \\
\hline Germany & 1,000 & 0,323 & 0,391 & 0,734 & 0,552 & 4 & 78,52 \\
\hline Greece & 0,090 & 0,169 & 0,483 & 0,416 & 0,235 & 10 & 33,43 \\
\hline Ireland & 0,082 & 0,033 & 0,956 & 0,997 & 0,225 & 11 & 32,01 \\
\hline Italy & 0,592 & 1,000 & 0,494 & 0,655 & 0,662 & 2 & 94,17 \\
\hline Netherlands & 0,221 & 0,119 & 1,000 & 0,825 & 0,384 & 6 & 54,62 \\
\hline Portugal & 0,066 & 0,059 & 0,683 & 0,373 & 0,177 & 15 & 25,18 \\
\hline Spain & 0,477 & 0,608 & 0,391 & 0,540 & 0,497 & 5 & 70,70 \\
\hline
\end{tabular}




\begin{tabular}{|c|c|c|c|c|c|c|c|}
\hline \multirow[b]{2}{*}{ Country } & \multicolumn{4}{|c|}{ Relative distances for: } & \multirow[b]{2}{*}{$\begin{array}{l}\text { Average } \\
\text { distance }\end{array}$} & \multirow[b]{2}{*}{$\begin{array}{l}\text { Final } \\
\text { rank }\end{array}$} & \multirow{2}{*}{$\begin{array}{c}\text { Position } \\
\text { to the } \\
\text { maximum } \\
\text { performance } \\
\text { unit (\%) }\end{array}$} \\
\hline & $\begin{array}{c}\text { Sales- } \\
\text { purchasing } \\
\text { value in retail } \\
\text { units }\end{array}$ & $\begin{array}{l}\text { Commercial } \\
\text { retail units }\end{array}$ & $\begin{array}{l}\text { Unemploy } \\
\text { ment rate }\end{array}$ & GDP/pers & & & \\
\hline Sweden & 0,111 & 0,055 & 0,782 & 0,860 & 0,253 & 9 & 35,99 \\
\hline Great Britain & 0,915 & 0,360 & 0,935 & 0,794 & 0,703 & 1 & 100,00 \\
\hline Czech Rep. & 0,057 & 0,101 & 0,518 & 0,233 & 0,162 & 17 & 23,04 \\
\hline Hungary & 0,047 & 0,169 & 0,705 & 0,222 & 0,188 & 14 & 26,74 \\
\hline Poland & 0,172 & 0,366 & 0,226 & 0,145 & 0,213 & 12 & 30,30 \\
\hline Slovakia & 0,017 & 0,049 & 0,237 & 0,173 & 0,076 & 19 & 10,81 \\
\hline Bulgaria & 0,014 & 0,093 & 0,358 & 0,068 & 0,075 & 20 & 10,67 \\
\hline Romania & 0,023 & 0,144 & 0,537 & 0,077 & 0,108 & 18 & 15,36 \\
\hline
\end{tabular}

Applying this hierarchy method, we obtained similar results to those obtained by applying the ranks' method. United Kingdom is the most well situated country (rank 1), followed by Italy, France and Germany. The last three countries, most disadvantaged were Bulgaria, Slovakia ad Romania. Italy realized 94\% of the first ranked country's performance, while France and Germany realized 78-79\%. The last countries realized only $10-15 \%$ of the maximum performance.

\section{Conceptual considerations in European retail trade activity}

We mention a few conceptual, theoretical specifications about shop-types in European space. Commercial retail units classify on some criteria (most times conventional), at regional, geographical level; these criteria are established by specific standards.

"Hypermarket" concept was first invented in 1966, by Jacques Pictet, the creator of a specialized shop LSA (Libre Service Actualités). In French acceptation, hypermarket is a discount-type store, with over $2500 \mathrm{~m}^{2}$ sale-surface, of which $35 \%$ is dedicated to nonfood products. It is usually placed outside the cities or towns, and has one or at most two levels. The first hypermarket in France was built in 1963 (Carrefour), followed shortly after that by E. Leclerc and Landreau (1964), Auchan (1967), Cora (1969) and Géant Casino (1970).

In an English definition, a hypermarket is a superstore that combines a supermarket and a departament store. It is an en-detail ,giant" with a lot of food-products and general products. Its surface is between 14000 and $20000 \mathrm{~m}^{2}$, the proper places for a hypermarket are peripherical zones of cities or near them.

In Germany, a hypermarket is a giant retailing store, with a surface between 5000 and $15000 \mathrm{~m}^{2}$; the products sold in a hypermarket are mostly food-products, but non-food products are important, too (30-40\% of products). 


\section{Hypermarket or supermarket? From where and how much buy European inhabitants?}

European buyers do their shopping in hypermarkets and supermarkets, in a great proportion. In 20 analyzed countries, there are over 6500 hypermarkets (according to the International Euromonitor) (with 27\% more in 2005 compared to 2000) and over 75000 supermarkets (at the end of 2005, with $2 \%$ more than in 2000).

In Romania, 11 years ago opened the first classical European supermarket; since then, urban population customs changed. Large store-chains became strong centers for buyers. As in the other European countries, the supply diversity, the supply volume and the promotional prices are the most important elements in attracting customers. Romania is far behind the other European countries, referring to the number of hypermarkets.

The purchasing value from hypermarkets, per inhabitant differs and depends on the number of hypermarkets, of demand-solvability and on buying-customs (Netherlands, Ireland and even Austria have less hypermarkets).

Graphic no. 3. The evolution of hypermarkets - number, in some European countries, in 2000-2005

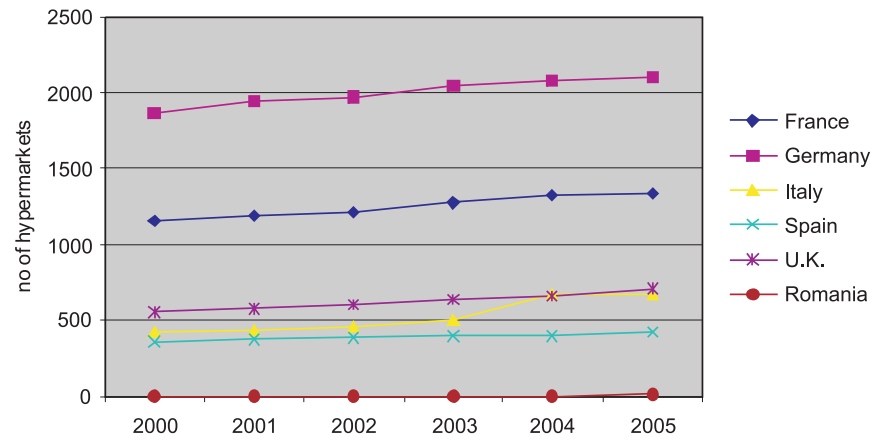

Source: National statistics, Euromonitor 2006, authors' direct research to primary sources (for Romania).

Graphic no. 4. Evolution of purchasing value from hypermarkets, per inhabitant in some European countries, in 2000-2005

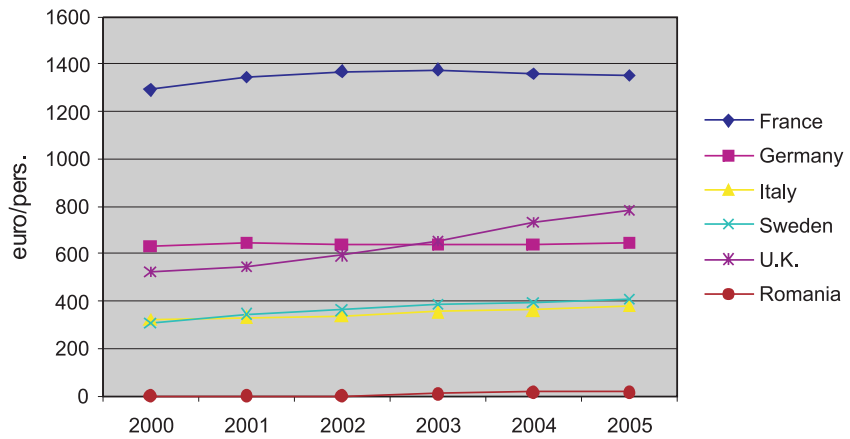

Source: National statistics, Euromonitor 2006 
In Bulgaria and Romania, the annual purchasing value from hypermarkets (for every person) is 14 , respectively 16 euros , but there is hope that it will significantly increase in 2007, until 2010.

Many producers and distributors are asking themselves about the changes in European and Romanian retail-sector, beginning with January 2007. What will happen with the small shops, if the large store-chains extend all over the country? What will be the prices evolution in small shops, when near every big city there will be one hypermarket and 4 or 5 supermarkets? Will the increase of the sales-agent number be justified or not?

Euromonitor Agency predicts that the evolution of hypermarkets in the next years will be as follows: the number of these stores will increase (in some countries even significantly), some of the producers have to change radically their distribution strategies and some of their communications strategies. At the same time, the products must be modified, the price-strategies too. The stores will have a greater economic power, as they'll increase their negotiation capability.

\section{Supermarket-type stores at European level}

As in hypermarkets' case, the definition of a supermarket differs from one country to another. In Germany, a supermarket is a store with a surface between $400-800 \mathrm{~m}^{2}$; in United Kingdom the supermarket is a self-service store, where food products and general products are sold, with lower prices, compared to other stores (for example: convenience store). They are one-level stores and are situated out or near the cities. In France, Belgium, Denmark, Spain and Italy, the specific law specifies that a supermarket is a retail store, with a sale-surface between $400-2500 \mathrm{~m}^{2}$, but with differences in each country. In Spain there are so-called large supermarkets (with a surface between 1500 and $2500 \mathrm{~m}^{2}$ ).

In most of the former European Union's countries (15 countries), the number of supermarkets haven't changed a lot, in some countries it have decreased (Denmark, Finland, France, Germany, Netherlands). In most of the cases, the decreases happened

Graphic no. 5. Evolution of supermarkets number, in some European, in 2000-2005

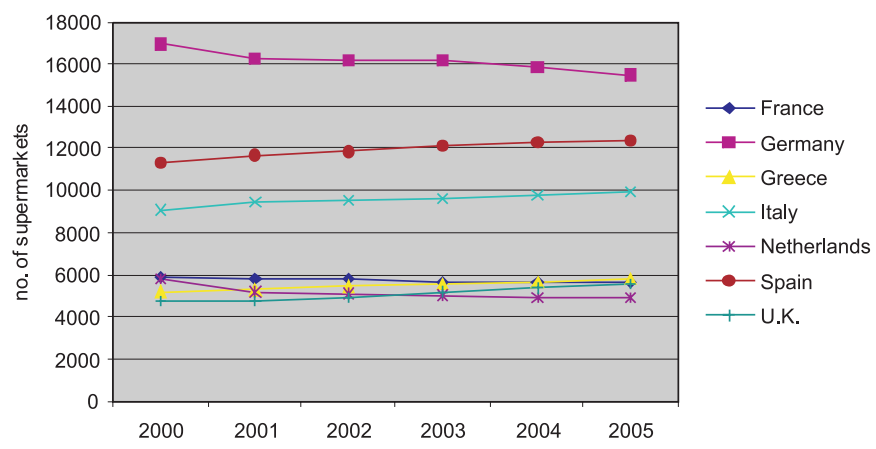

Source: National statistics, Eurostat, Euromonitor 2006. 
because of the extremely powerful competition and because of the domination (pressure) of large transnational store-chains. In many countries, the apparently high number of supermarkets (in Romania, too), is caused by the non-existence of a minimum standard specification in this store's definition.

According to the International Euromonitor 2006 predictions, the number of hypermarkets increases (but insignificantly) at European level, the rise will be of $3 \%$ in 2006-2010, compare to 2006. The number of supermarkets will increase in 2006-2010 in a larger proportion ( $9 \%$ compare to 2006$)$. The purchasing value in supermarkets will increase, too, especially in most recent European Union's countries.

Next, we applied the same hierarchy methods mentioned before for criteria referring to the retail-domain: number of hypermarkets and supermarkets, the purchasing value in hypermarkets and supermarkets per inhabitant in 2005 (table 4).

The application-results of the ranks' method and the relative distance method are: on the top-places there were situated France, U.K., Germany, followed by Italy and Spain; on the last places: Slovakia, Bulgaria and Romania. The best situated countries, according

Table 4. Number of hypermarkets and supermarkets, the purchasing value in hypermarkets and supermarkets per inhabitant in 2005, in some European countries

\begin{tabular}{|c|c|c|c|c|}
\hline Country & $\begin{array}{c}\text { Number of } \\
\text { hypermarkets }\end{array}$ & $\begin{array}{c}\text { The purchasing value in } \\
\text { hypermarkets per pers. } \\
\text { (euro/pers.) }\end{array}$ & $\begin{array}{c}\text { Number of } \\
\text { supermarkets }\end{array}$ & $\begin{array}{c}\text { The purchasing value in } \\
\text { supermarkets per pers. } \\
\text { (euro/pers.) }\end{array}$ \\
\hline Austria & 73 & 146,14 & 2146 & 791,01 \\
\hline Belgium & 91 & 365,05 & 2289 & 985,90 \\
\hline Denmark & 171 & 835,87 & 1705 & 904,07 \\
\hline Finland & 123 & 749,48 & 1054 & 1126,69 \\
\hline France & 1333 & 1352,86 & 5631 & 1044,45 \\
\hline Germany & 2100 & 644,24 & 15470 & 700,60 \\
\hline Greece & 23 & 105,07 & 5757 & 623,25 \\
\hline Ireland & 1 & 6,34 & 1415 & 2724,86 \\
\hline Italy & 676 & 375,80 & 9954 & 650,83 \\
\hline Netherlands & 8 & 5,54 & 4892 & 1091,06 \\
\hline Portugal & 76 & 334,39 & 859 & 362,42 \\
\hline Spain & 424 & 257,42 & 12384 & 993,34 \\
\hline Sweden & 114 & 405,29 & 2546 & 1261,90 \\
\hline Great Britain & 708 & 786,81 & 5545 & 1138,47 \\
\hline Czech Rep. & 178 & 353,83 & 625 & 157,47 \\
\hline Hungary & 93 & 323,42 & 540 & 149,64 \\
\hline Poland & 277 & 180,01 & 973 & 79,55 \\
\hline Slovakia & 93 & 205,69 & 350 & 141,63 \\
\hline Bulgaria & 12 & 13,70 & 311 & 66,08 \\
\hline Romania & 7 & 15,99 & 734 & 32,86 \\
\hline
\end{tabular}

Source: National Statistics, Eurostat, Euromonitor International. 
to the relative distance method was Germany; U.K. realized $70 \%$ out of Germany's performance, and Italy $-58 \%$. The last ranked countries realized only $2 \%$ out of maximum performance.

The proportion of supermarkets out of total number of retail commercial units, in territorial profile, in 2005, varied from 3-4\% in ex-socialist countries, that recently joined the European Union (Poland 3,01\%o; Hungary 3,6\%; Bulgaria 3,77\%o) and almost 70\%o in Denmark, followed by Germany (54\%o) and Sweden (52\%o). In Romania, in 2005, only $5,75 \%$ out of total number of retail commercial units were supermarkets.

Regarding the hypermarkets' share in total number of retail units, this is even lower than supermarkets' share. It varied in 2005 from 0,03\%o (Ireland) and 0,05\%o (Romania) to $7,35 \%$ in Germany or $7,01 \%$ in Denmark

Graphic no. 6. European countries' position compared to maximum performance unit

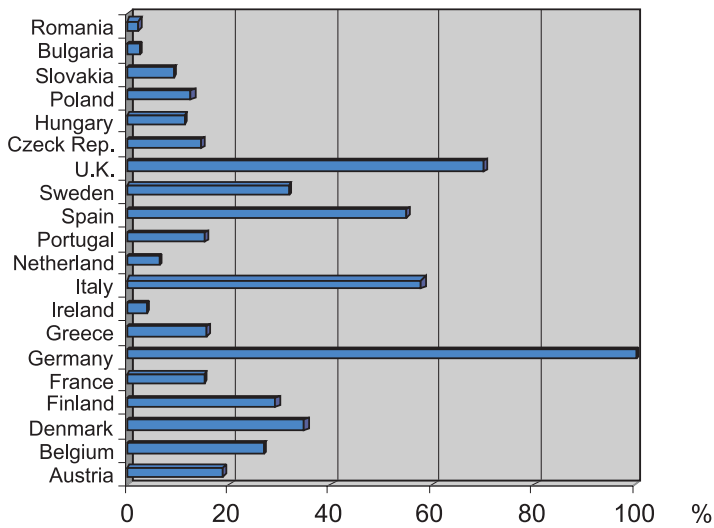

Graphic no. 7 Supermarkets' proportion out of total number of retail commercial stores in some European countries, in 2005

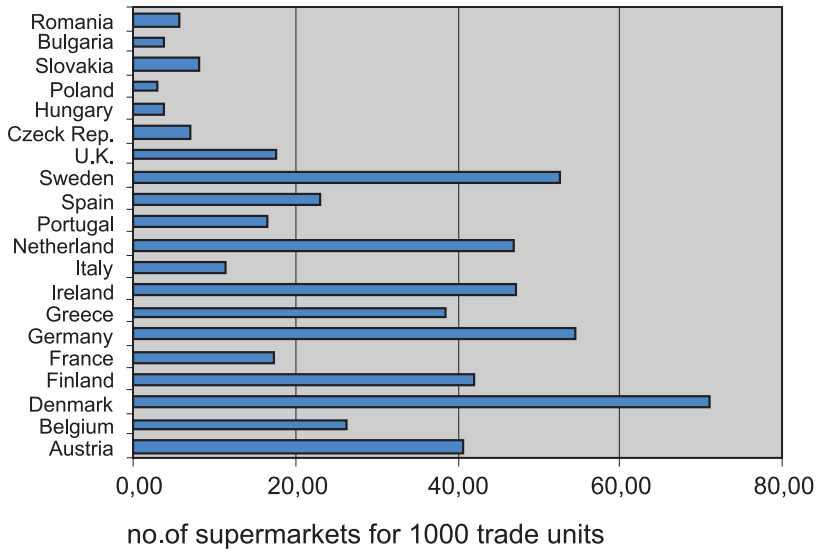


The ratio between the supermarkets' purchasing value and hypermarkets' purchasing value, in 2005 had a large variability from country to country. While in northern European countries (like Ireland or Netherlands) the purchasing value per inhabitant from supermarkets was 430 times greater, respectively 200 times greater than the purchasing value from hypermarkets per inhabitant, in Poland, Czech Republic and Hungary, the ratio was less than 1: the purchasing value from supermarkets, per inhabitant represented only $45 \%$ out of the one in hypermarkets. In most countries (in 15 out of 20 countries) the ratio was less than 1 , the average purchasing value from supermarkets per inhabitant being greater than the one in hypermarkets.

\section{Conclusions}

We appreciate that the retailing trade activity in Romania and in other European countries will develop in a spectacular way, the most dynamic and significant operators being hypermarkets and supermarkets, components of great transnational store-chains. As regarding Romania, in our opinion, the retail trade activity will have an increasing trend. But, having a low purchasing value from hypermarkets and supermarkets per inhabitant, of only 100 euros (2010), our country will have a long way to do, to get closer to the other European countries' standards. It is, however, difficult to predict what will happen in the next 2-3 years to little commercial shops, especially to those that sell food-products of any kind, as well as to the great majority of distributors that supplies the little commercial shops in towns and villages.

\section{References}

Alam A., The New Trade Theory and Its Relevance for Developing Countries, The World Bank, 1994, Banai-Kashani R., A new method for site suitability analysis: the analytic hierarchy process, [in:] Environmental Management, volume 13, no 6, nov. 1989, Springer New York.

Burgstaller J., Landesmann M., Trade Performance of East European Producers on EU Markets: an Assessment of Product Quality", The Vienna Institute for Comparative Economic Studies, Research Report No. 255, April 1999.

Gauthier R., Reaching France's retail food system, AgExporter, June 2004.

Ghiță S., Statistics of Labor Resources, Meteor Press Printing House, Bucharest 2005.

Hamson L., Eastern promise: the hottest growth opportunities in Central and Eastern Europe and Russia, in Grocer, Sept. 2006.

Heller, H. R., (1968): „International Trade. Theory and Empirical Evidence”, Prentice-Hall Inc

Kangas A., Leskinen P., Kangas J., Comparison of fuzzy and statistical approaches in multicriteria decisionmaking, Forest Science 53, 2007.

Leskinen P., Kangas J., Rank reversals in multi-criteria decision analysis with statistical modelling of ratio-scale pairwise comparisons, Journal of the Operational Research Society 56, 2005.

Leskinen P., Kangas A.S., Kangas J., Rank-based modelling of preferences in multi-criteria decision making, European Journal of Operational Research 158, 2004.

Rondinelli D., Applied methods of regional analysis: the spatial dimensions of development policy, Geographical Review, vol. 76, no 1 (Jan. 1996). 
Țițan E., Statistics. Theory and applications in tertiary sector, Meteor Press Printing House, Bucharest 2002.

Statistical Yearbook of Romania 2006, National Institute of Statistics 2006.

Statistical Yearbook of Romania 2005, National Institute of Statistics 2006

European Comission Country Report 2003, European Comission Delegation in Romania, European Union, Bucharest, 2003, November the 5th

www.euromonitor.com

www.eurostat.com

www.insse.ro

www.omc.com 